\title{
When Does Might Make Right? Using Force for Regime Change
}

John Linarelli

Touro Law Center, jlinarelli@tourolaw.edu

Follow this and additional works at: https://digitalcommons.tourolaw.edu/scholarlyworks

Part of the Ethics and Political Philosophy Commons, Human Rights Law Commons, International Law Commons, Jurisprudence Commons, Law and Philosophy Commons, Law and Society Commons, Rule of Law Commons, and the Social Policy Commons

\section{Recommended Citation}

40 J. SOCIAL PHIL. 343

This Article is brought to you for free and open access by the Faculty Scholarship at Digital Commons @ Touro Law Center. It has been accepted for inclusion in Scholarly Works by an authorized administrator of Digital Commons @ Touro Law Center. For more information, please contact Iross@tourolaw.edu. 


\title{
WHEN DOES MIGHT MAKE RIGHT? USING FORCE FOR REGIME CHANGE
}

\author{
John Linarelli*
}

The aim of this paper is to identify the moral grounds for the use of armed force by one state or a group of states, against a state (the "target state"), when the intention of the intervening state(s) is to achieve a fundamental change in the character of the political and legal institutions of the target state. To put the question within a liberal context, is a state or a collectivity of states ever justified, or indeed even obligated, to use force to assist in bringing democracy and rule of law to another state? Despite its imprecision and its ubiquitous use in the political science literature, I use "regime change" as shorthand to describe the use of armed force whose moral justification is investigated here. ${ }^{1}$ My limitation of the regime change terminology helps to make it more precise, in the sense that I use it only to refer to cases in which regime change is the actual reason for the military intervention, not the consequence of it. ${ }^{2}$ To avoid any difficulties associated

\footnotetext{
* Professor of Law, University of La Verne College of Law, Ontario, California, john_linarelli@ulv.edu. This paper was presented as a work in progress at the Association of American Law Schools Mid-Year Meeting in Vancouver, B.C., Canada, June 17-20, 2007. I am grateful to Mary Ellen O’Connell for comments provided as panel chair. Please do not cite or distribute without permission.

${ }^{1}$ Michael Walzer uses the term in the preface to the latest edition of Just and Unjust Wars. Michael Walzer, Just and Unjust Wars (New York: Basic $4^{\text {th }}$ ed. 2006), p. ix. Allen Buchanan uses "forcible democratization.” Allen Buchanan, "Institutionalizing the Just War," Philosophy and Public Affairs 34(1) (2006), pp. 2-38. I do no use Buchanan's phrase because I want to be clear that force in my account is not to be used to compel democracy but to force bad governments to allow their peoples to govern themselves justly. In using the different terminology I intend to provide no commentary on the merits on Buchanan's account.

${ }^{2}$ In the preface of the latest edition of Just and Unjust Wars, Walzer distinguishes between cause and consequence. Walzer, Just and Unjust Wars, pp. ix-x. Of course, the "cause' terminology has its origins in just war theory and traces back to Aquinas. Thomas Aquinas, Summa Theologica, Fathers English Dominican Province trans. (Christian Classics 1981), Part II, Question 40.
} 
with accessing the intentions or motives of collectivities and their leaders, I refer to reasons for action that governments rely on to use force.

The question posed has obvious relevance to current affairs. The actual yet perhaps not fully articulated justification for the March 2003 invasion of Iraq was regime change. The characteristics of the Saddam Hussein regime made all the difference. Many states have weapons of mass destruction (WMDs), including the United States itself, its coalition partners, and its NATO allies, but the US government does not consider WMDs in these states as a justification for invasion. ${ }^{3}$ As Walzer explains, "it was the character of the regime that made Iraq dangerous: The US government claimed that Saddam's regime was inherently aggressive and inherently murderous. Just as it had committed aggression in the past, so it had massacred its own people in the past, and American leaders insisted that, in this case, the past was prologue. What happened before would happen again unless the regime was replaced."” For those who object to the 2003 Iraq war and ensuing occupation, their objections seem to come from a moral conviction that using force to accomplish regime change is illegitimate, that it causes too much harm and that peaceful alternatives ought to be pursued. I seek to clarify those convictions here.

Having narrowed the question to one of "regime change intervention," I must acknowledge that in the non-ideal world it is difficult to separate reasons for action and the consequences of those reasons. Moreover, governments often have more than one reason for using force. A mixture of reasons to support intervention has historically been a central feature of government decision-making. ${ }^{5}$ A question closer to the way governments make policy might be framed as which reason predominates or what is the operative reason, apart from the political rhetoric, for the intervention. I have opted to state the question as I have for purposes of clarity and precision.

\footnotetext{
${ }^{3}$ Walzer, Just and Unjust Wars, pp. xii-xiii.

${ }^{4}$ Ibid.

${ }^{5}$ Ibid., p. 101; Jane Stromseth. David Wippman \& Rosa Brooks, Can Might Make Rights? Building the Rule of Law After Military Interventions (Cambridge: Cambridge University Press 2006), p. 3: "Frequently, of course, the motives behind military interventions will be complex and mixed. . . . In the age of globalization, there can often be no neat distinctions between "humanitarian" concerns and "security" concerns.”
} 
Regardless of the reasons governments offer to justify the use of force, they often engage in post-conflict reconstruction. ${ }^{6}$ Key to post-conflict reconstruction is efforts to bring rule of law, constitutional reform and democracy to the target state. In all of these cases, some entity, usually the intervener's government, viewed a return to the status quo as unacceptable. The interveners may value law and democracy instrumentally, as necessary to produce a state that values peace and pursues peaceful relations with neighbors and within the broader international community. ${ }^{7}$ But an instrumental view is not the only view and the argument for bringing institutions of justice to a state, or at least assisting in doing so, could certainly be seen as having a deontological justification. ${ }^{8}$

In their recent book on the military intervention - rule of law connection, Can Might Make Rights: Building the Rule of Law after Military Intervention, legal scholars Jane Stromseth, David Wippman and Rosa Brooks bring to our attention that forcing people to

6 Stromseth, Wippman \& Brooks, Can Might Make Rights provide the details of post-conflict reconstruction from the 1990s onwards.

${ }^{7}$ Empirical political science literature informs that democratic states tend not to start armed conflicts. See, e.g, Bruce M. Russett, Grasping the Democratic Peace: Principles for a Post-Cold War World (Princeton University Press 1993); John Oneal \& Bruce M. Russett, "The Classical Liberals Were Right: Democracy, Interdependence, and Conflict, 1950-1985, International Studies Quarterly 41(2) (1997): 267-294: Zeev Moav \& Bruce M. Russett, "Normative and Structural Causes of Democratic Peace, 1946-1986" The American Political Science Review 87(3) (1993): 624-638. The literature is discussed in John Linarelli, "Peacebuilding," Denver Journal of International Law and Policy 24 (1996): 253-283.

${ }^{8}$ A Kantian approach values peace noninstrumentally, as respect for the dignity of persons. In Perpetual Peace, Kant's first definitive article for perpetual peace is that the constitutions of every state must be republican. Kant explains:

the republican constitution does offer the prospect of the result wished for, namely perpetual peace; the ground of this is as follows. When the consent of the citizens of a state is required in order to decide whether there shall be war or not (and it cannot be otherwise in this constitution), nothing is more natural than that they will be very hesitant to begin such a bad game, since they would have to decide to take upon themselves all the hardships of war (such as themselves doing the fighting and paying the costs of the war from their own belongings, painfully making good the devastation it leaves behind them, and finally - to make the cup of troubles overflow- a burden of debt that embitters peace itself, and that can never be paid off because of new wars always impending); on the other hand, under a constitution in which subjects are not citizens of the state, which is therefore not republican, [deciding upon war] is the easiest thing in the world; because the head of state is not a member of the state but its proprietor and gives up nothing at all of his feasts, hunts, pleasure palaces, court festivals, and so forth, he can decide upon war, as upon a kind of pleasure party, for insignificant cause, and can with indifference leave the justification of the war, for the sake of propriety, to the diplomatic corps, which is always ready to provide it.

Immanuel Kant, "Perpectual Peace,” in Immanuel Kant, Practical Philosoophy, Mary J. Gregor trans. \& ed. (Cambridge: Cambridge University Press 1996), pp. 323-324. The empirical political science literature could be said to vindicate Kant's insights. See Allen Buchanan, Justice, Legitimacy and SelfDetermination: Moral Foundations for International Law (Oxford: Oxford University Press 2004). Buchanan characterizes Kant’s point as the "Democratic Peace Hypothesis," which, he says, "recent liberal theorists" have revived. See also Walzer, Just and Unjust Wars, p. xi. 
become democratic and liberal seems like something in the nature of a contradiction. ${ }^{9}$ How do we force people to accept rule of law, democratic order, and principles of justice? Worse still, what if the intervention is of dubious legality, as was the 2003 invasion of Iraq (10 $^{10}$ To borrow from Kant very loosely here, actions of the sort taken in Iraq suggest to us a contradiction in conception: we certainly should not be able to will a general principle in which states may use illegal force to promote rule of law. Stromseth, Wippman and Brooks explain that their book "is less concerned with political and legal theory than with what seems to work on the ground, and what does not."11 They continue: "nonetheless, when it comes to creating 'the rule of law' in post-intervention settings, we are convinced that understanding what does and doesn't work requires some basic historical and theoretical insights.” ${ }^{212}$ The aim of this paper is to provide what lawyers would characterize as theoretical insights, though a better characterization would be as what philosophers characterize as conceptual and normative-explanatory insights. ${ }^{13}$ I cannot provide these insights for the entire book, but rather identify the moral conditions for one sort of military intervention.

A well-developed literature exists on when it is morally permissible for a state to use armed force. My account differs from these in three ways. First, I develop the moral requirements for using force to bring about or more accurately, to assist citizens in the target state in bringing about, regime change. ${ }^{14}$ About as close as the literature gets to dealing with my question is in addressing the moral justification for humanitarian

\footnotetext{
${ }^{9}$ Stromseth, Wippman and Brooks at p. 312 explain:

The rule of law elevates reason over force and rights over mere might. This creates a difficult irony. Regardless of the specific background to any given intervention, interveners have the capacity to intervene for one overriding reason: the possession of superior military might." They continue: "But even when a particular intervention is widely seen as legitimate, the fact remains that on the ground, interveners are present because they have greater military power than other contenders. From Bosnia to East Timor to Afghanistan and Iraq, interveners are in a position to promote the rule of law mainly because they have a superior capacity to capture, disable, or kill most of those who get in the way. Although they may not possess a complete monopoly on the use of force, they certainly have the biggest guns on the block, and they can use those guns, directly or indirectly, to coerce local actors into cooperating with rule of law initiatives.

${ }^{10}$ For various views on the legality of the 2003 Iraq war, see "Agora: Future Implications of The Iraq Conflict,” American Journal Of International Law 97(3) (2003), pp. 553-642.

${ }^{11}$ Stromseth, Wippman \& Brooks, Can Might Make Rights?, p. 10.

${ }^{12}$ Ibid.

${ }^{13}$ See Joseph Raz, The Morality of Freedom (Oxford: Oxford University Press 1986) pp. 65-66.

${ }^{14}$ Throughout, I use the term "citizen" to refer to the populations of states. My intention is not to convey any additional meaning in the use of the term.
} 
intervention to stop or prevent imminent violations of basic human rights. As I explain below, the grounds for humanitarian intervention come from what I identify as the Human Rights Principle. I rule out the Human Rights Principle as providing reasons for using force to bring about regime change. Instead, I develop a Self Governance Principle as the grounds for regime change intervention. Second, almost all of the literature to-date conceptualizes moral reasons for use of force as a rights, justifications or permissions. I take a different approach, developing the notion of an obligation or duty to use force and on contexts in which no such obligation exists. ${ }^{15}$ I agree with Onora O'Neill that "the most significant structures of ethical concern can be expressed in linked webs of requirements, which are better articulated by beginning from the perspective of agents and their obligations rather than that of claimants and their rights." ${ }^{216}$ The focus is dual, on the obligations of intervening states to protect foreigners and the obligations of intervening states to protect their own citizens from harm. The obligation I describe is collective; it is an obligation of individual states but it can only be accomplished collectively, through international institutions. Third, my approach focuses on the necessary conditions for bringing a new legal and constitutional order to the target state. Incorporating conditions for success does not entail only the calculation of costs and benefits. The account is grounded in deontological and interpretive considerations. Incorporating success conditions into the account helps to make the duty one that goes beyond the familiar weaknesses in duties of beneficence.

My account shares affinities with David Luban's limiting principle on humanitarian intervention, which he sets forth in his paper on the Kosovo intervention: "If the aftermath of intervention is anarchy or an unstable truce, the war should be waged only if the interveners are prepared for a lengthy occupation or an exercise in state building." 17

\footnotetext{
${ }^{15}$ I use the terms "duty" and "obligation" interchangeably. My aim is to understand whether a moral duty exists to intervene to bring about regime change, and if so, the conditions for that moral duty to arise. KokChor Tan takes a similar approach to these terms in his paper on humanitarian intervention, "The Duty to Protect," in Terry Nardin \& Melissa S. Williams, Nomos XLVII Humanitarian Intervention (New York: New York University Press 2006), pp. 84-116, 112 n. 1.

${ }^{16}$ Onora O'Neill, Towards Justice and Virtue: A Constructive Account of Practical Reasoning (Cambridge: Cambridge University Press 1996), p. 4.

${ }^{17}$ David Luban, “Intervention and Civilization: Some Unhappy Lessons of the Kosovo War," in Pablo de Greiff \& Ciaran Cronin, Global Justice and Transnational Politics (Cambridge MA: MIT Press 2002), p. 79-115, 89.
} 
To Luban, a "crucial point" is "no follow-through, no intervention.",18 He concludes, "otherwise, interventions are like tossing a life jacket to a shipwrecked victim but then leaving the victim adrift in the middle of the ocean."19 My case differs from Luban's in that Luban is accounting for consequences, not when the motivating reason for the force is regime change. Unlike Luban, I seek an obligation in the first instance for throwing the lifejacket, but his casting of principles in moral terms gives us hints on how to construct a moral theory to support regime change intervention.

Suppressing a great deal of law and institutional detail, we can summarize the three main legal grounds for military intervention as self-defense, threats to international peace and security, and humanitarian grounds. ${ }^{20}$ The third ground - humanitarian intervention - is the subject of ongoing legal controversy. Law is, after all a normative order located within institutions, and from an institutional perspective, it is a disputed legal point whether interventions solely for humanitarian reasons require UN Security Council action. $^{21}$

Many view the international law on the use of force, and international law in other areas, as morally inadequate. The inadequacies at least partly stem from the normative grip of sovereignty on international law. As Luban explains, sovereignty is not a moral concept. $^{22}$ Since international law in its current form respects the notion of sovereignty, it comes as hardly a surprise that from a moral standpoint, a deep dissatisfaction with international law persists. ${ }^{23}$ This dissatisfaction will persist until international law includes a morally sensitive notion of state legitimacy. This paper tries to expose the fault lines of the dissatisfaction in the law when it comes to the question of military

\footnotetext{
${ }^{18}$ Ibid.

${ }^{19}$ Ibid.

${ }^{20}$ See UN Charter Art. 51, Chap. VII; Christine Gray, International Law and the Use of Force (Oxford: Oxford University Press $2^{\text {nd }}$ ed. 2004).

${ }^{21}$ Simon Chesterrman, Just War or Just Peace? Humanitarian Intervention and International Law (Oxford: Oxford University Press 2001), chap. 2.

${ }^{22}$ David Luban, “Just War and Human Rights,” Philosophy and Public Affairs 9(2) 1980, pp. 160-181.

${ }^{23}$ In his Inaugural Lecture at the University of Cambridge, James Crawford argues that "it is hardly surprising that under international law (apart from treaties), there was no general endorsement of a principle of democracy. Crawford identifies six features of "classical" international law that "were deeply undemocratic, or at least were capable of operating in a deeply undemocratic way." James Crawford, "Democracy and the Body of International Law," in Gregory H. Fox \& Brad R. Roth eds., Democratic Governance and International Law (Cambridge: Cambridge University Press 2000), pp. 91-113.
} 
intervention as part of a strategy to bring legitimacy to states through legal and democratic reform.

The grounds I elucidate below may be used to inform international law but they cannot be directly transposed into legal principles. ${ }^{24}$ When it comes to understanding the law-morality connection, I accept the view that moral principles serve a function like that posited by Ronald Dworkin and T.M. Scanlon. ${ }^{25}$ States, moreover, just might have an obligation to reform international law so that it conforms to moral principles. ${ }^{26}$

It may seem that I give short shrift to institutions, and in particular to the role of the UN Security Council. That is not my intention. Security Council action presupposes a threat to international peace and security, the grundnorm for Security Council action. ${ }^{27}$ One of the questions explored below is whether there should be grounds apart from threat to international peace and security for the use of force. To state the question more precisely, one of the questions explored below is whether there should be grounds for using force in which no threat to international peace and security serves as justification. I explore moral reasons directly and avoid resort to a separate standard - threat to international peace and security - for justification. The account below may inform U.N. practice or Charter revision. My main concern is with coming up with normative principles that go beyond the Charter, which may inform Charter revisions.

\footnotetext{
${ }^{24}$ I employ the strategy Avishai Margalit and Joseph Raz describe as follows: It is assumed throughout that states and international law should recognize [a right of self-determination only if there is a sound moral case for it. This does not mean that international law should mirror morality. Its concern is with setting standards that enjoy the sort of clarity required to make them the foundations of international relations between states and fit for recognition and enforcement through international organs. These concerns give rise to special considerations that should be fully recognized in the subtle process of applying moral principles to the law. The derivation of legal principles from the moral premises is never a matter of copying morality into law. Still, the justification of the law rests ultimately on moral considerations, and therefore those considerations should also help shape the contours of legal principles.
}

Avishai Margalit \& Joseph Raz, "National Self-Determination,” The Journal of Philosophy 87(9), p. 439461, 439.

${ }^{25}$ Scanlon's excellent treatment of these questions is in T.M. Scanlon, "The Aims and Authority of Moral Theory," Oxford Journal of Legal Studies 12(1): 1-23.

${ }^{26}$ See in particular Allen Buchanan’s Illegal Legal Reform Justification, in Allen Buchanan, "Reforming the International Law of Humanitarian Intervention" in J.L. Holzgrefe \& Robert O. Keohane, Humanitarian Intervention: Ethical, Legal, and Political Dilemmas (Cambridge: Cambridge University Press 2003), pp. 130-173. An excellent study of how customary international law is formed is O.A. Elias \& C.L. Lim, The Paradox of Consensualism in International Law (The Hague: Kluwer Law International 1998).

${ }^{27}$ UN Charter Arts. 2(4), 39, 42. 
Nothing said here is intended to suggest that military force should be used under any circumstances other than as a last resort. Legal reformers advocating a change in the legal principles towards responsibility to protect have consistently maintained that military force should be the option of last resort. ${ }^{28} \mathrm{I}$ accept these arguments as sound and they merit no further discussion here.

\section{REGIME CHANGE AS HUMANITARIAN INTERVENTION}

An intuitive place for lawyers to locate regime change intervention is in an expanded version of humanitarian intervention. Lawyers state the putative legal justification of humanitarian intervention in the Human Rights Principle: countries may use force to protect "basic" human rights. This is the standard formulation that international lawyers support in trying to carve out a third reason for use of force, beyond self-defense and Security Council authorization. ${ }^{29}$ Ian Brownlie defines putatively permissible humanitarian intervention as "the threat or use of armed force by a state, a belligerent community, or an international organization, with the object of protecting human rights. ${ }^{30}$ Tighter definitions have been offered, to limit protection to only the most "basic" of human rights or to stop the most serious of human rights violations, such as to stop genocide. J. L. Holzgrefe provides a precise definition of humanitarian intervention as "the threat or use of force across state borders by a state (or group of states) aimed at preventing or ending widespread and grave violations of the fundamental human rights of individuals other than its own citizens, without the permission of the state within whose territory force is applied." ${ }^{31}$ Rwanda and Sudan are examples of circumstances in which humanitarian intervention was justified but failed to materialize. Kosovo is often suggested as an example of a humanitarian intervention, undertaken collectively by

\footnotetext{
${ }^{28}$ See, e.g., Report of the High-Level Panel on Threats, Challenges and Change, A More Secure World: Our Shared Responsibility (United Nations 2004), p. 67. For an explanation of these proposals, see Mary Ellen O'Connell, "The Counter-Reformation of the Security Council," Journal of International Law and International Relations 2(1) 2007, pp. 207-221.

${ }^{29}$ Chesterman, Just War or Just Peace, p. 1.

${ }^{30}$ Ian Brownlie, "Humanitarian Intervention," in John N. Moore ed., Law and Civil War in the Modern World (Baltimore: Johns Hopkins University Press 1974), p. 217. The quote is found in Chesterman, Just War or Just Peace, p. 1.

${ }^{31}$ J.L. Holzgrefe, "The Humanitarian Intervention Debate," in Holzgrefe \& Keohane, Humanitarian Intervention, p. 18.
} 
NATO, though NATO members avoided the characterization, and the characterization remains contested. ${ }^{32}$

The Human Rights Principle cannot support regime change intervention. Its conception of human rights is too restrictive to support regime change intervention. Moreover, the scope of the Principle extends to the human rights relevant to regime change only with great difficulty.

As for the restrictiveness of the Human Rights Principle, all commentators agree that only the most fundamental of human rights justify humanitarian intervention. Luban argues that the human rights that trigger intervention should be the "socially basic human rights" of subsistence and security. ${ }^{33}$ Protecting these rights, however, does not call for post-conflict reform. ${ }^{34}$ Indeed, what may be left in power is an illegitimate state by Luban's definition and by definitions of other moral theorists who have considered the question. ${ }^{35}$ Michael Walzer's approach contains similar limitations. One of Walzer's limited "rules of disregard" of sovereignty is when a government massacres, enslaves or expels its segments of its population. ${ }^{36}$

Preventive humanitarian intervention might be an avenue to achieve regime change. But the Human Rights Principle does not justify preventive humanitarian intervention or at least not intervention when human rights violations are not imminent. ${ }^{37}$ The common understanding of the Human Rights Principle is that for it to do the work of justifying the use of force, the atrocities must be ongoing or imminent at the time the force is used. If

\footnotetext{
${ }^{32}$ See, Stromseth, Wippman and Brooks, pp. 35-39; Luban, "Intervention and Civilization: Some Unhappy Lessons of the Kosovo War.”

${ }^{33}$ David Luban, "The Romance of the Nation-State, Philosophy and Public Affairs 9(4) (1980), pp. 392397; David Luban, “Just War and Human Rights,” Philosophy and Public Affairs 9(2) (1980), pp, 160-181.

${ }^{34}$ I certainly do not argue that governments cannot engage in post-conflict reform after they have stopped actual or prevented imminent human rights violations. I want to keep, however, the notions of cause and consequence distinct. Post-conflict reform can be a consequence of humanitarian intervention.

${ }^{35}$ Some influential accounts, however, provide the illegitimate states are not entitled to respect. A canonical justice-based account is Charles Beitz, Political Theory and International Relations (Princeton: Princeton University Press). Beitz maintains that only states that conform to principles of justice are autonomous sources of ends entitled to respect. Non-intervention doctrines apply only to these states. Buchanan's account is similar. Buchanan, Justice, Legitimacy, and Self-Determination, pp. 233-247. Buchanan maintains that only legitimate states are morally justified in exercising political power. According to Buchanan, a state has such moral justification if and only if it credibly protects basic human rights through processes that respect human rights.

${ }^{36}$ Walzer, Just and Unjust Wars, p. 90. Walzer later added expulsion when writing in response to critics. Michael Walzer, "The Moral Standing of States: A Response to Four Critics," Philosophy and Public Affairs 9(3) (1980), pp. 209-229.

${ }^{37}$ Buchanan, Justice, Legitimacy and Self-Determination, p. 443.
} 
the justification for the intervention is to prevent future non-imminent human rights violations, then it is preventive in character. The aim of such intervention is that bringing rule of law and democracy to a state will prevent the sorts of extraordinary human rights abuses that humanitarian intervention is designed to stop, as well as bring about other laudable behaviors. This is not humanitarian intervention, but intervention for purposes of regime change.

Nor does the Human Rights Principle justify humanitarian intervention to remedy past human rights violations. ${ }^{38}$ An intervention for such reasons again would be for the purposes of regime change. The reason for the lack of connection between the Human Rights Principle and intervention and past human rights violations is logically simple. The Principle justifies use of force to stop human rights violations. If no human rights violations are occurring, then no action by a state triggers its application. If no human rights atrocities are occurring then the Human Rights Principle, which justifies intervention to stop human rights atrocities, does not support humanitarian intervention. If a state has in the past violated basic human rights on a massive scale, but no longer does so, then the Human Rights Principle possibly justifies remedies other than regime change, such as compensation paid to victims, truth commissions, criminal prosecutions of the abusers, either domestically or internationally, and so on. These sorts of actions are ongoing now, in, for example, the International Criminal Tribunal for the former Yugoslavia, the International Criminal Tribunal for Rwanda, and the South African Truth and Reconciliation Commission.

In sum, the reasons for the impermissibility of humanitarian intervention to remedy past human rights abuses share similarities with reasons for the impermissibility of humanitarian intervention to prevent future human rights abuses. Both kinds of interventions have regime change, not protecting vulnerable populations from extraordinary human rights violations, as their main purpose.

The 2003 invasion of Iraq is a classic failure of the humanitarian intervention justification on both these grounds. The only humanitarian justification the interveners in Iraq (the US and the UK principally) could possibly cite to would have been to ongoing and current mass atrocities being committed by Saddam Hussein and his regime. No

${ }^{38}$ Ibid. 
mass atrocities were ongoing at the time, and the coalition did not cite a humanitarian justification as a reason for the invasion, at least not directly or persuasively. ${ }^{39}$ The interveners could not cite the mass atrocities for which Hussein was tried and hanged, because he committed those in the early 1990s, and they thus could not serve as a justification for military action in 2003. The interveners could not cite the probability of future mass atrocities either. That would be preventive humanitarian intervention, which is not permitted by the Human Rights Principle.

The only way to get the Human Rights Principle to do the work of providing reasons for intervention for the purpose of regime change is to expand the coverage of "basic" human rights protected by the Principle to include a right to democratic governance. We would need to revise substantially the current form of the Human Rights Principle.

Some legal scholars have sought just such an expansion. The most sanguine view of the state of international law at this time is that an "emerging right" or "emerging norm" of democratic governance exists. ${ }^{40}$ If this emerging right is or becomes international law, it might justify humanitarian intervention to bring about democracy and rule of law in a target state. A number of legal scholars advocate such a right, but it seems clear that no persistent and widely followed custom or opinio juris exist as yet. It is doubtful that a rule of customary international law will "emerge” for some time. ${ }^{41}$ Some might say that the putative norm reflects only an American view. ${ }^{42}$

To the extent the legal arguments are positivistic and source driven, moreover, they may be too conventional to provide support for a moral account. A good deal of the reasoning in the legal literature is conventional in nature. Finding a customary

\footnotetext{
${ }^{39}$ Though of course humanitarian reasons lurked in the political background. See the White House's background paper for the President, "A Decade of Deception and Defiance: Saddam Hussein's Defiance of the United Nations, Sept. 12, 2002, http://www.whitehouse.gov/news/releases/2002/09/iraqdecade.pdf (last viewed June 15, 2007). For a statement of the reasons for the invasion by government lawyers, see William H Taft IV and Todd Buchwald, "International Law and the War in Iraq," in "Agora: Future Implications of The Iraq Conflict,” American Journal of International Law 97(3) (2003), pp. 553-642.

${ }^{40}$ The origins of the discussion in the legal literature are in Thomas M. Franck, "The Emerging Right to Democratic Governance,” American Journal of International Law 86(1) (1992): 46-91.

${ }^{41}$ James Crawford sets out the canonical skeptical case in his Inaugural Lecture at the University of Cambridge. James Crawford, "Democracy and the Body of International Law,” in Fox \& Roth, pp. 91-120.

${ }^{42}$ Crawford explains that "the idea has found at least some support from commentators within and even outside the United States.” Ibid., p. 106. I taught in the UK for almost five years and I recall raising the question of the emerging right of democratic governance in a meeting and receiving a dismissive rebuttal to the effect, "that's only something Americans are thinking about." Regrettably, I cannot recall the details of the discussion.
} 
international law norm is an exercise in both legal reasoning and political or sociological analysis. Human rights instruments and state practice, at both the multilateral and regional levels, are surveyed, and in them are found the recognition in state practice of various rights to political participation, from which we can make the argument, inferentially, that an emerging right of democratic governance exists. The inferential argument is that these sources express a widespread and uniform custom and sense of obligation necessary for opinio juris. Such an account tells us about conventions that exist in the global society of states, and they may assist empirically, in using a wide reflective equilibrium procedure to revise the Human Rights Principle so that it does the work of morally justifying using force in appropriate regime change cases. This is a far more indirect approach than the one I propose below.

But it suggests a variation on a theme. A common set of circumstances in many humanitarian interventions is that to stop the atrocities it is necessary to overthrow the oppressive government and begin the installation of a new one. This should have occurred in Rwanda. Rwanda is a failure of the international community to act when confronted with an overwhelming human rights disaster. If there had been a humanitarian intervention into Rwanda to stop the massacre of the Tutsis and protect them from further harm, it would have been necessary to overthrow the Hutu regime. In Kosovo, NATO intervened military in the mid-1990s to stop Serbian ethnic cleansing, but "grave problems still remain" despite post-conflict reconstruction efforts by the international community on a massive scale. ${ }^{43}$ In the non-ideal world, neat separations of questions along conceptual lines rarely present themselves. It is sometimes difficult to distinguish protecting vulnerable persons from atrocities and regime change. All of this may be true, but it does not mean that we should avoid clarity in our grounds for using force. Given that the Human Rights Principle in its present form requires that atrocities must be ongoing or imminent at the moment of decision, it does not do the work of justifying regime change either when no atrocities are ongoing or imminent or when regime change is unnecessary to stop the atrocities. We need to a more finely grained Principle. In sum, the Human Rights Principle in its present form does not justify regime change as the animating purpose of the intervention.

\footnotetext{
${ }^{43}$ Stromseth, Wippman \& Brooks, p. 66.
} 
Finally, even if the Human Rights Principle could be revised to encompass a human right to democratic governance, it does not follow that an obligation exists for states (or their citizens) to provide the right to the citizens of other states. If a right to democratic governance can be found in human rights conventions and state practice, then it seems clear that states who fail to provide the right to their own citizens violate the human rights of their own citizens, but it is by no means clear that other states violate the human rights of the citizens of other states. It is the obligation of the state that is the possible target of intervention to provide the right, not the state that is considering intervention. Again, The Human Rights Principle does not do the work of justifying regime change intervention.

\section{Regime Change As its Own ReAson}

Avoiding the problems with the Human Rights Principle, I propose the Self Governance Principle as moral justification for regime change intervention. ${ }^{44}$ The Self Governance Principle is as follows: legitimate states (or their citizens) have a collective obligation to intervene militarily in an illegitimate state (the "target state") when a substantial likelihood exists that (i) the population in the target state will form a new government in a manner meeting the moral and conceptual conditions for self determination, which includes the conversion of the target state into a legitimate state and (ii) post-conflict reform will a bring about a legal system meeting the conceptual conditions for the law to have practical authority to the target state's population. If these conditions are not met, states have an obligation to refrain from using force solely for purposes of regime change. I specify below how the Self Governance Principle is mandatory: it is in the nature of a duty of justice, not beneficence. It is obligatory not supererogatory.

I could specify a third practical authority condition relating to international law, that the use of armed force must meet widely accepted standards of international legality. But

\footnotetext{
${ }^{44}$ One question not for exploration here is whether the Self Governance Principle has its source in human rights. A state that fails to comply with principles of justice - an illegitimate state - certainly violates human rights. It is just that the Self Governance Principle does not make those human rights violations the trigger for intervention. To the extent that a human rights justification requires that we assist peoples in transitioning from an illegitimate to a legitimate state, then the Self Governance Principle may be seen as a further specification supported by a broader Human Rights Principle. As I explain, however, my focus is not on rights but on obligations.
} 
I think specification of these additional conditions might be circular, in that the above conditions, if they inform the content of international law, will bring about compliance with this third condition.

I accept Charles Beitz's and Allen Buchanan's notion of the source of legitimacy of a state. To use Beitz's formulation, "only states whose institutions satisfy appropriate principles of justice can legitimately demand to be respected as autonomous sources of ends." ${ }^{45}$ Beitz is careful to explain that he does not specify the content of the principles of justice that states should respect. ${ }^{46}$ In a footnote, he explains that he uses "appropriate principles of justice" "to suggest that it is possible that different principles of justice may apply to different types of societies in view of variations, e.g., in levels of socioeconomic development. ${ }^{\text {} 47}$ Justice-based conceptions of state legitimacy, while controversial from a legal perspective, are not controversial from a moral perspective. The idea of adhering to principles of justice is just a way of saying that state institutions must respect each citizen of the state. It is a deontologically based conception of the state, one that grounds state legitimacy in principles of political morality. Beitz's approach assists in avoiding the problem of ignoring the fact of pluralism that Walzer brings out in Just and Unjust Wars. Walzer's concern with too narrow a definition of state legitimacy is we might fail to respect historic communities within states. ${ }^{48}$

The Self Governance Principle provides that only legitimate states share in the collective obligation to intervene. From a prudential standpoint, illegitimate states, under the definitions I use, are too unstable to have responsibilities to intervene militarily in the affairs of other states. From a moral standpoint, illegitimate states have no standing to

\footnotetext{
${ }^{45}$ Beitz, Political Theory and International Relations, p. 81.

${ }^{46}$ Ibid., p. 70.

${ }^{47}$ Ibid., p. 81, n. 23.

${ }^{48}$ Walzer, "The Moral Standing of States." Beitz's approach also seems compatible with a Rawlsian approach that includes both liberal democratic peoples and decent peoples, though it is difficult to look to Rawls' The Law of Peoples because it provides little guidance on the subject of use of force in the contexts discussed here. In The Law of Peoples Rawls does make limited points about humanitarian intervention. We might be able to extend his duty of assistance of well-ordered peoples to populations in need of help in self-determination efforts in what Rawls calls outlaw states. Rawls formulates his duty of assistance as: "Peoples have a duty to assist other peoples living under unfavorable conditions that prevent their having a just or decent political and social regime." John Rawls, The Law of Peoples (Cambridge MA: Harvard University Press 1999), p. 37. Rawls says: "The long-term goal of (relatively) well-ordered societies should be to bring burdened societies, like outlaw states, into the Society of well-ordered Peoples. Wellordered peoples have a duty to assist burdened societies." ${ }^{, 48}$ Ibid., p.106. Rawls distinguishes, however, burdened societies from outlaw states. Well-ordered societies in the Rawlsian framework are "liberal peoples" and "decent peoples."
} 
use force. Beitz argues that states differ from natural persons, in that unlike natural persons, states "lack the unity of consciousness and the rational will that constitute the identity of persons."49 It is a reason not to give illegitimate states autonomy because natural persons deserve to be respected as autonomous sources of ends and protected from such states. ${ }^{50}$ Hence, we can hold legitimate states to have obligations and illegitimate states not to have them. The analogy to natural persons would be that illegitimate states are not persons entitled to respect as persons.

The concept of state legitimacy applies across the board. In addition to the obligation to use force inuring only to legitimate states, a moral necessity condition within the notion of self determination is that the end-result of any intervention will be a legitimate state. Legitimate states may use force only to assist in the creation of legitimate states. This is not a controversial condition.

The self determination condition is Millian: the need for change must come from the inside. ${ }^{51}$ To Mill, external force is never sufficient for producing the conditions for selfdetermination. Mill argued that political communities must seek their own freedom. I do not go as far as Mill, however, with his stern doctrine of self-help. In my account, the question whether political communities are in the process of seeking political freedom is hermeneutical: whether outsiders can know when the conditions for self determination exist. Though this condition is a difficult hurdle, there will be good cases. One of my main relaxations of Millian principles is my argument that external force alone is never sufficient for producing the conditions for self determination. The Self Governance Principle permits external assistance when its conditions are met.

The self determination condition contained in the Self Governance Principle differs from the usual conceptions. It takes territory and nationality as unalterable givens. State integrity is accepted as is. I do not use the self determination terminology to refer to the usual case in which it is used, that of secession. The Self Governance Principle does not cover the case of separating out a group with a clear cultural, ethnic, or other identity for self governance in their own state or in a kind of millet multiculturalist order within a

\footnotetext{
49 Beitz, Political Theory and International Relations, p. 81.

50 Ibid.

51 John Stuart Mill, “A Few Words on Non-Intervention,” Gertrude Himmelfarb, ed., John Stuart Mill: Essays on Politics and Culture (Garden City, NY: Anchor Books, 1963), pp. 368-384.
} 
state. $^{52}$ The concern of the Self Governance Principle is in how states as they are currently constituted may be made legitimate through the use of collective force from the outside. It may seem odd that self determination, a moral concept, is subservient to the non-moral, political concept of the sovereignty of an existing state. But the idea is simple: all things being equal, citizens of a state are better off in an ethical sense, of being able to live their plans of life more fully, if they can govern themselves justly. Legitimate states have a moral duty to assist peoples living in unjust states to transform unjust governments to just ones.

A way of understanding the notion of self determination as it is incorporated in the Self Governance Principle is to break it into two parts: "self” and "determination." As for "self," the focus is on a single identity that almost all persons have: political identity with a state. ${ }^{53}$ The concern of the Self Governance Principle is, for example, on Iraqis or Italians or Rwandans, not on Kurds or Sunnis or Shiites or Calabrese or Genoese or Hutu or Tutsi. There may be other identities in the target state, but they do not matter either for purposes of determining whether regime change intervention is morally justified. Regime change matters for these other identities to the extent that a legitimate state comes into existence that adheres to principles of justice and these principles provide cultural, ethnic, religious, sexual, and other identities the circumstances in which to flourish, but these other "sub-national" identities are not to be recognized in the first instance in setting the conditions for regime change intervention. Recognizing the rights of sub-national identities to self determination thus has a clear ethical component, but to recognize their right as sufficient for self determination under the Self Governance Principle would be to change the status of their identity as it is recognized in their society. Their own society recognizes their identities as sub-national. To recognize a sub-national identity as having a claim of national self determination is to convert a demand for respect within a political community to one for secession, for respect as a political community.

\footnotetext{
${ }^{52}$ For a discussion of millet multiculturalism, see Kwame Anthony Appiah, The Ethics of Identity (Princeton: Princeton University Press 2005), pp. 71-79

53 I say "almost all" persons because, as international law recognizes, a person may be stateless. Ian Brownlie, Principles of Public International Law (Oxford: Oxford University Press $5^{\text {th }}$ ed. 2003), p. 424. Statelessness, however, is rare.
} 
Why do we care about self determination? The answer lies in the concept of selfhood. Many answers have been offered to this question, but mine is rooted in liberalism: autonomy. ${ }^{54}$ Autonomy, in its fullest moral sense, recognizes persons as deliberative, active agents. Autonomous persons are not passive, not mere responders to incentives. Autonomy necessarily includes the freedom to govern oneself. Self governance is thus one of the necessary features of autonomy. Kant conceptualized moral self governance as autonomous persons willing and legislating moral laws. In the public or political space, Kantian self governance is produced by reliance on principles of right and democratic (Kant said republican) institutions. According to Daniel Philpott, democracy is "the activity of governing oneself, of exercising one's autonomy in the political realm." ${ }^{55}$ For purposes here, we can say that democracy is the fullest form of exercise of autonomy, but that we may leave open other forms, so long as they meet the basic conditions of autonomy promotion found in principles of justice. Justice is the irreducible principle; though it would seem at least almost always to lead to a democratic public order, I do not want to leave out the possibilities of other just orders. Many of our life choices, from the most trivial of obtaining a driver's license, to the most fundamental, such as protection of basic liberties, are provided within the context of political authority. All persons thus have a basic right to decide how they exercise their autonomy within the political realm. We care about self determination in a conditional sense: if citizens of a state value their self determination within that state and want regime change in that state, to bring about a state that respects principles of justice, then outsiders ought to respect those values.

The self determination condition should be understood hermeneutically. Its hermeneutical features go to "determination." Global pluralism is an obvious social fact. The process of determining whether a population in a target state wants regime change is an interpretive exercise. The inquiry is in justifying regime change because it is appropriate for the target state population because of its history and traditions, its social

\footnotetext{
${ }^{54}$ That autonomy is the animating reason to value self determination does not mean that autonomy is divorced from identities other than the one that counts for determining membership in a state. See Appiah, The Ethics of Identity; Charles Taylor, Sources of the Self: The Making of Modern Identity (Cambridge MA: Harvard University Press 1989). In Just and Unjust Wars, Walzer sees states as comprised of historic communities that deserve respect. Michael Walzer, "The Moral Standing of States,” pp 210-216.

${ }^{55}$ Daniel Philpott, “In Defense of Self Determination,” Ethics 105 (1995), pp. 352-385, p. 357.
} 
practices and the kind of community it is. It is a process of discovering the meaning of regime change to the target state's population, using what Georgia Warnke characterizes as a hermeneutic circle:

We shall start by understanding a particular action or practice in terms of our initial assumptions about the context of which it is a part, that is in terms of an initial understanding of a framework of norms, values and activities. We shall then deepen or even revise that understanding of the framework in terms of a more thorough understanding of each of the parts that compose the framework, including the action or practice we initially tried to understand in terms of it. The goal is that of ironing smooth all the wrinkles and glitches in our interpretation so that we attain a selfconsistent understanding in which our interpretation of the meaning of each practice, norm and arrangement of the society confirms our understanding of the whole and in which our understanding of the whole substantiates our understanding of each part. ${ }^{56}$

Hermeneutic principles can assist in the search for a commitment by the target state population to regime change. This task may not be as difficult as it seems. As Philpott suggests in discussing the traditional concept of self determination, "if . . . the expressed preference for self-government, not then identifying characteristics of the group, is decisive, then the problem of finding objective criteria is avoided, at least in theory. The standard is instead subjective: it simply does not matter which traits define a seceding group; we know one when it announces, campaigns, or takes up arms for its dream of self-determination. ${ }^{, 57}$ Similar criteria may hold for the narrower kind of nationalitydriven self determination that is the subject of the Self Governance Principle, but we should put the criteria through the hermeneutic process to assess their meaning.

An example of how to develop a hermeneutical understanding of self determination is in the decision to invade Iraq in March 2003. I cannot provide a full interpretation of events leading up to the war here; that would be the subject of entirely different paper. But I can provide a start to such an account, to show how we might go about using hermeneutics to understand whether the Iraqis as a national identity group met the conditions for national self determination sufficient for the United States and its coalition partners to overthrow the Hussein regime. At and near the time of the 2003 invasion, Bush Administration representatives made a number of statements to the effect that the

\footnotetext{
${ }^{56}$ Georgia Warnke, Justice and Interpretation (Cambridge MA: MIT Press 1993), p. 22.

${ }^{57}$ Philpott, "In Defense of Self Determination, p. 365.
} 
conditions in Iraq were similar to those in France and Germany after World War II and that US troops would be "greeted as liberators."58 Giving the Bush Administration the benefit of the doubt, it apparently took only the first step in interpreting events in Iraq. They went only so far as understanding a particular action or practice in terms of their initial assumptions about the context of which it is a part; they apparently understood the Iraqi historical and cultural context as something like that of Germany and Japan after World War II. They failed to move on to deeper or revised understandings or to seeking coherence of the parts with the whole. Francis Fukuyama seems to have gotten it right in his critique of Bush Administration policy:

Prior to the Iraq War, there were many reasons for thinking that building a democratic Iraq was a task of complexity that would be nearly unmanageable. Some reasons had to do with the nature of Iraqi society: the fact that it would be decompressing rapidly from totalitarianism, its ethnic divisions, the role of politicized religion, the society's propensity for violence, its tribal structure and the dominance of extended kin and patronage networks, and its susceptibility to influence from other parts of the Middle East that were passionately anti-American. ${ }^{59}$

The Bush Administration thus made some crucial misinterpretations of the conditions for regime change in Iraq. ${ }^{60}$

\footnotetext{
${ }^{58}$ A number of such Bush Administration statements can be found in the transcripts of various news sources. Vice President Cheney made such a statement in a March 16, 2003 Meet the Press interview, four days before the invasion of Iraq. Then Deputy Secretary of Defense Paul Wolfowitz made similar statements at the time, including at a VFW conference on March 11, 2003 and before the House Budget Committee on February 27, 2003. Then Chief of Staff Andrew Card made similar statemens in a Fox News interview on January 26, 2003.

${ }^{59}$ Francis Fukuyama, “The Neoconservative Moment,” The National Interest, July 1, 2004.

${ }^{60}$ To understand how a hermeneutic or interpretive approach works, we can contrast it with the method that dominates public policy discussions, that of cost-benefit analysis. In "analytical" social science methods, the self is seen as totally undifferentiated. All selves are the same in all times and all historical and cultural contexts. This is Martin Hollis's “plastic man.” Martin Hollis, Models of Man: Philosophical Thoughts on Social Action (Cambridge: Cambridge University Press 1977). The methods employed to understand the conditions of self determination here take a passive and hollow view of persons and examine the incentives undifferentiated persons have to prefer or not prefer national self determination based solely on evaluations of self interest, and assume that all persons will act on these preferences deterministically. Here, we employ instrumental conceptions of costs and benefits, and attempt an entirely objective evaluation from a purely detached point of view, of whether the people of the target state support national self determination. The value of national self determination is understood exhaustively in the question: will regime change improve the welfare of the target state's populace? Plastic man methods are popular in government circles but they have failed to produce an adequate understanding whether the conditions for national self determination truly exist in a way that supports an event as traumatic as the use of force to bring about regime change.
} 
The second condition identified in the Self Governance Principle is that post-conflict reform should bring about a legal system meeting the conceptual conditions for the law to have practical authority to the target state's population. The need for this condition arises from the problems that Stromseth, Wippman and Brooks bring out on the implausibility of using force to create a legitimate legal system. Plausible post-conflict reform requires much more than simply creating legal institutions and writing laws. ${ }^{61}$ Stromseth, Wippman and Brooks explain that "without a widely shared cultural commitment to the idea of the rule of law, courts are just buildings, judges are just bureaucrats, and constitutions are just pieces of paper.”62 They contend that post-conflict reform requires the development within the target state population of a "widely shared cultural and political commitment to the values underlying these institutions and codes."63 How to comply with these conditions after an external force conquers the target state is problematic. They explain that "in post intervention societies ... the tension between the law's appeal to reason and the realities of coercion is particularly glaring, and greatly complicates efforts to create rule of law cultures." ${ }^{\circ 4}$ They continue:

Possession of superior force thus creates both opportunities and challenges for interveners. On the one hand, interveners have perhaps a unique capacity to foster positive change. . . . But interveners can compel cooperation - or at least the outward forms of cooperation - they can easily spearhead the creation of new institutions or reformed legal codes. . . . But in other ways, possession of superior force only increases the difficulties faced by interveners eager to help foster a rule of law culture. The example of the intervention itself tends to undercut subsequent arguments made by interveners about the value of reason and legal process over force, particularly if the intervention was of contested legality, as in Iraq. If the intervention itself is read as an object lesson about the irrelevance of law as a constraint on power, people on the ground may be particularly resistant to efforts to convince them of the virtues of the rule of law....65

\footnotetext{
${ }^{61}$ As for the latter point of too much focus on institution building and law drafting, the strategies Stromseth, Wippman and Brooks criticize are the signal features of so called "law and development" projects of the post Cold War period, regardless of whether they follow on from an armed conflict. In addition to their use in post-conflict reform, they are also used more generally in law reform projects solely to promote the economic development of developing countries.

${ }^{62}$ Stromseth, Wippman and Brooks, Does Might Make Rights?, p. 76.

${ }^{63}$ Ibid., p. 78.

${ }^{64}$ Ibid., p. 313.

${ }^{65}$ Ibid., p. 313-14.
} 
Stromseth, Wippman and Brooks are not doing philosophy and admit what they say "is not intended to stand up to rigorous philosophical critiques.”66

But they identify an important insight that analytical legal philosophers have been exploring for some time. Here we have the opportunity to make analytical jurisprudence an "applied" philosophy. It is by now beyond serious challenge that force is not the source of legal authority. HLA Hart began the twentieth century discussion of the practical authority of law in his distinguishing between being obliged and being obligated. ${ }^{67}$ The source of practical authority that Hart identified are those found in socially accepted hierarchies. Social acceptance brings legitimacy to these hierarchies. People have attitudes about being obligated by the law. Law makes a normative demand or claim on free and rational persons who have the capacity to respond to reasons. Legal reasons come from the conventions that produce the law and not from the content of the reasons themselves (as they do in morality), but that does not matter for purposes of understanding the nature of the practical authority of law. People develop an attitude about what officials offer as law as the right kind of reason to act in a certain way. Legal authority is possible because of a kind of shared conviction of what law is. So in analytical jurisprudence we have a theory about law that is based on the idea of normative commitment and which respects the autonomy of persons. This is a way of conceptualizing legal obligation in much the same way as moral philosophers conceptualize moral obligation - as something that makes legitimate claims on us.

With these understandings at hand, the practical authority condition is necessary in any moral justification of the use of force to bring about regime change. It is at least implausible to suggest that a legitimate state, that is, one that follows principles of justice, could ever form without its legal system having the kind of practical authority that analytical jurisprudence elucidates for law. This is not the place to restate what has already been worked out by others on how the practical authority of the law is a necessary condition for human freedom. If law makes a legitimate claim to obedience on persons, in a way that respects the freedom of each person, then the practical authority conditions must be met. ${ }^{68}$

\footnotetext{
${ }^{66}$ Ibid., p. 78.

${ }^{67}$ H.L.A. Hart, The Concept of Law (Oxford: Oxford University Press 1961), p. 82.

${ }^{68}$ See Joseph Raz, The Morality of Freedom (Oxford: Oxford University Press), pp. 22-105.
} 
The final component of the Self Governance Principle is its formulation as a collective duty. The literature to-date on humanitarian intervention conceptualizes moral grounds for that kind of intervention as either a justification or permission to intervene or as an obligation to intervene. The "majority" of the literature, if there is such a thing, conceptualizes the moral grounds for humanitarian intervention as a question of justification or permission. ${ }^{69}$ Here we face a possible difficulty. Force is usually justified as a response to wrong. ${ }^{70}$ In the humanitarian intervention context, the wrong is clear; human rights atrocities are in the process of being committed or are imminent. What is the wrong in regime change intervention? More precisely, what is the wrong creating a collective moral duty to intervene for regime change purposes?

The strategy employed to address these concerns is to see if the Self Governance Principle can be upheld in a contractualist framework, using T.M. Scanlon's form of contractualism. How does the Self Governance Principle fare in a contractualist account? Can no one reasonably reject it? I want to use Scanlon's contractualism to understand whether the Principle is well formed as a collective moral duty of legitimate states.

A key feature of the Scanlonian form of contractualism is its conception of reasonable rejection. $^{71}$ I cannot restate Scanlon's account here in detail but I identify some of its features, particularly if they might become obstacles to supporting a duty in the Self Governance Principle. A summary statement of contractualism's formula of universal law of sorts is that moral action is governed by principles for the general regulation of behavior that are not reasonably rejectable by persons with the same motivations as to the appropriate reasons for rejection. In contractualist terms, legitimate states, or more properly their citizens, and target state citizens, should regulate themselves by principles that are not reasonably rejectable to every one of them in each state. Only individuals on their own behalf can object to principles. Interpersonal aggregation of burdens and benefits is thus barred save in limited circumstances. ${ }^{72}$ What counts as a reason for

\footnotetext{
${ }^{69}$ The two papers that specify a strict moral duty of justice are Kok-Chor Tan, "The Duty to Protect," in Terry Nardin \& Melissa S. Williams, eds., Nomos XLVII Humanitarian Intervention (New York: NYU Press 2006), pp. 84-116 and Carla Bagnoli, "Humanitarian Intervention as a Perfect Duty: A Kantian Argument, in Nardin \& Williams, Humanitarian Intervention, pp. 117-139.

${ }^{70}$ Bagnoli, "Humanitarian Intervention as a Perfect Duty," p. 127.

${ }^{71}$ Scanlon formulates reasonable rejection in various ways. See T.M. Scanlon, What We Owe to Each Other (Cambridge MA: Harvard University Press 1998), pp. 4, 153.

${ }^{72}$ Scanlon permits aggregation in a "tie," a situation in which the moral seriousness of, say, two states of
} 
acceptance or rejection of a principle depends on the strength of the reason alone. A weaker opposing reason cannot outweigh a stronger reason simply because more people accept the weaker reason. So, in search of a principle no one can reasonably reject, we compare the merits of reasons to accept or reject the principle, and we restrict ourselves to comparing the reasons only of individuals. All of this entails "that any individual can reasonably reject a principle when she can propose an alternative principle to which no other single individual has an equally strong objection.”73 Reasons include the consideration of burdens and benefits on individuals. Well being is an acceptable reason, but it is not the only one, and it is tempered by the concept of reasonableness and by the prohibition on interpersonal aggregation. We cannot reasonably reject a principle only because of the burdens it imposes on us, but that principle applies to all other individuals too. The reasonableness of our rejections requires a judgment about the suitability of principles that must be based in mutual recognition from a moral perspective. The process of selecting principles works like reflective equilibrium, though I do not want to get into precise comparisons here. The end of the process of principle selection is to identify a principle that no one can reasonably reject and that has the weakest individual objection to it.

The most direct way to access the contractualist moral argument in the Self Governance Principle is to examine the burdens and benefits of both target and intervening state citizens. The burdens and benefits of many citizens in the intervening and target states are similar. I do not group persons, but I address the account to representative citizens of the states in question. My interest is in finding the citizens who will suffer the greatest burdens, as they may well have reasons to reject the Self Governance Principle.

The burdens on intervening states’ citizens are substantial. The intervening states’ citizens who will be most burdened will be those who have to fight in the conflict and

affairs is equivalent, but one situation involves harm to more people than the other. In such a situation, it is permissible to choose the alternative that causes harm to the fewer number of persons. In situations not involving ties, however, the overwhelming majority of situations, we must look to burdens on individuals to choose the appropriate principles. Ibid., p. 5.

${ }^{73}$ Elizabeth Ashford, “The Demandingness of Scanlon’s Contractualism,” Ethics 113 (2003), pp. 273-302, p. 280. Ashford influenced the above abbreviated discussion of contractualism. 
their families. ${ }^{74}$ Also burdened in the intervening states are persons who suffer resource deprivation to fund the intervention. Armed conflicts typically involve massive expenditures from the public budget, diverting scarce resources from domestic projects designed to benefit a state's citizens, to benefit foreigners. ${ }^{75}$

Given these burdens, it would seem that intervening states' citizens could reasonably reject the Self Governance Principle. Three features of the Principle, however, may make it unlikely to be reasonably rejectable to the intervening states' citizens.

First, the duty is collective. Making the duty collective limits the sacrifice the population of each state must provide. ${ }^{76}$ Collectivity mitigates the problem of disproportionate costs to any single state's citizens. Collectivity also mitigates the problem of disproportionate benefits. The citizens of all states generally have reason to reject single state obligations because they could provide powerful states with opportunities for strategic behavior. The collectivity of the duty specified in the Self Governance Principle eliminates or at least mitigates disproportionate benefits inuring to any single state. If the duty is collective, states cannot take advantage of their power, but neither will they bear disproportionate burdens. The collective feature of the duty facilitates global stability. ${ }^{77}$

\footnotetext{
${ }^{74}$ For a discussion of the legitimacy of humanitarian intervention to the citizens of intervening states, see Allen Buchanan, "The Internal Legitimacy of Humanitarian Intervention," The Journal of Political Philosophy 7(1) (1999), pp. 71-87. Buchanan argues that if a state is seen as an "instrument for justice" rather than as a "discretionary association," then the legitimacy of humanitarian intervention to the citizens of the intervening state could be established. In a contractualist approach to justifying either humanitarian or regime change intervention to the citizens of the intervening state, the function of a state as an instrument for justice would go to the reasonableness or unreasonableness of rejecting the principle justifying the intervention.

${ }^{75}$ I leave aside the difficulties of casually connecting resource deprivations to military spending in a complex institutional environment.

${ }^{76}$ In contexts outside of regime change intervention, others have made collective duty arguments, but support their arguments differently. Allen Buchanan, "Institutionalizing the Just War," Tan, "The Duty to Protect," and Bagnoli, "Humanitarian Intervention as a Perfect Duty." Buchanan perhaps comes closest to my case, but his argument is about preventive war. I have avoided preventive war doctrines because they are grounded in notions of self defense. My Self Governance Principle has nothing to do with self defense. A more directly Kantian line into collectivity is possible but would require much more than could be said here. Summarily, and avoiding the debate about whether Kant recognized supererogation, the idea is that Kantian duties to aid others are not duties of only one person, but are to be equally shared. Jens Timmons, "Good but Not Requred? - Assessing the Demands of Kantian Ethics” Journal of Moral Philosophy 2.1 (2005) pp. 9-27, p. 25.

${ }^{77}$ It cannot be permissible for states to intervene on an individual basis. The Self Governance Principle exhausts the courses of action. I specify above, along with the Self Governance Principle: "If these conditions are not met, states have an obligation to refrain from using force solely for purposes of regime change.”
} 
Second, the collective duty is indirect in the sense of requiring assistance through the formation of just and efficacious international institutions to do the work of intervention. It is a duty of justice something like what Rawls proposes individuals have in domestic societies: "the most important natural duty is that to support and to further just institutions."78 Rawls elaborates the duty as having two parts: "first, we are to comply with and to do our share in just institutions when they exist and apply to us; and second, we are to assist in the establishment of just arrangements when they do not exist, at least when this can be done with little cost to ourselves." ${ }^{, 79}$ Buchanan extends the natural duty of justice to the international realm. A contractualist account can support that duty. Regardless of whether a Rawlsian basic structure or any other form of social cooperation exists at the international level, each person has a "limited obligation to help create structures that provide all persons with access to just institutions. ${ }^{80}$ Buchanan explains that the "natural" modifier means that the duty applies to us as persons. We can limit the duty with the restriction that it applies to persons with means; we cannot ask the poorest in developing countries to discharge this duty. Buchanan's duty rests on Kantian considerations appealing to a contractualist view. It rests partly on what Buchanan calls the Moral Equality Principle: "all persons are entitled to equal respect and concern.”81 In Kantian terms, all persons are to be treated as ends. ${ }^{82}$ In addition, the duty of justice relies on Buchanan's Equal Regard Principle, that "treating persons with equal concern and respect requires helping to ensure that they are treated justly." ${ }^{83}$ Just legal institutions are required for people to be treated justly. ${ }^{84}$ All of these principles are reflected in the contractualist-based Self Governance Principle. The self determination condition in the Self Governance Principle covers much of the conceptual territory. The Self Governance Principle specifies the conditions inherent in any form of Kantian influenced contractualist argument: recognition respect. To put it more broadly, self

\footnotetext{
${ }^{78}$ John Rawls, A Theory of Justice (Cambridge MA: Harvard University Press rev. ed. 1991), p. 293. I owe this attribution to Buchanan, "The Internal Legitimacy of Humanitarian Intervention,” p. 83.

${ }^{79}$ Rawls, A Theory of Justice, pp. 293-94.

${ }^{80}$ Buchanan, Justice, Legitimacy, and Self Determination, p. 86.

${ }^{81}$ Ibid., p. 87.

${ }^{82}$ Ibid.

${ }^{83} \mathrm{Ibid}$.

${ }^{84}$ Ibid.
} 
determination is what deontological moral theories are all about.

Third, substantial benefits may accrue to the intervening states' citizens under the Self Governance Principle. They have reason to accept the Principle because legitimate states tend not to be aggressive or start wars. This point was discussed in the Introduction.

The target state's citizens should reasonably accept the Self Governance Principle as the only alternative to their dilemma. They live in an illegitimate state, one that fails to conform to principles of justice. The self determination condition specified in the Self Governance Principle guarantees that they are vitally interested in regime change. The practical authority condition specified in the Self Governance Principle protects them from the use of force to impose an illegitimate legal and constitutional order upon them. Unless the citizens of the target state receive military assistance, they will continue to be subjected to illegitimacy in their political life. They will be severely burdened by their lack of freedom.

Some target state citizens will suffer substantial burdens as a result of intervention. Certainly we should take into account that many in the target state may die or suffer serious injury as a result of military action. For them, the collective duty argument does not mitigate the considerable burdens them may suffer, and, it is not only their military that is in harm's way. The problem of harm to innocents poses a formidable moral difficulty for any use of force: how can a principle not be reasonably rejectable to those "civilians" - those who do not take part in the fighting - who will be killed or injured? They are being asked to die or face serious injury to support state legitimacy. The answer to this question is partly in the concept of a generic reason. Though contractualism specifies no veil of ignorance, the reasons to be evaluated are not those of identified persons but of persons in general. We have to rely not on reasons of specific individuals but on "commonly available information about what people have reason to want." "85 We look to what persons have reason to want "in virtue of their situation, characterized in general terms." 86 These parameters advise us to determine well being on the basis of "interests that everyone has reason to be concerned with."87 Scanlon provides as an

\footnotetext{
${ }^{85}$ Scanlon, What We Owe to Each Other, p. 204.

${ }^{86}$ Ibid.

${ }^{87}$ Ashford, Demandingness of Scanlon's Contractualism, p. 277.
} 
example that people have "strong reasons to want to avoid bodily injury ... and to have control over what happens to their own bodies." ${ }^{\not 8}$ So, we must specify even generic reasons restrictively if they involve death or bodily injury. We do not rely on the reasons of individuals who are fully situated in the armed conflict, but on generic reasons of citizens of the target state. The Self Governance Principle cannot be reasonably rejected by the target state civilians if the following limitations are taken into account. First, the Principle in no way limits state obligations to adhere to laws of war, including proportionality and necessity principles. Second, as explained in the Introduction, nothing said in this paper is intended to suggest that military force is to be other than as a last resort. The last resort concept ties into the necessity concept; there must be not alternatives to use of force. Scanlon mentions alternatives or the lack of them as relevant to reasonable rejection. ${ }^{89}$ Finally, the Self Governance Principle specifies a significant benefit for the citizens of the target state, who, by the success conditions mandated in the Principle itself, are ready for national self determination in the form of a legitimate state, that is, one that will begin to comply with principles of justice.

In summary, we can compare reasons for rejection and acceptance of the Self Governance Principle by each person in the target and intervening states, and likely conclude that the Principle is not reasonably rejectable by anyone. Of course, to reach this conclusion, we have to assume that persons have similar reasons based on similar circumstances, but we can still posit worst case scenarios, such as examining the case of persons who will be casualties in any intervention, in the assessment. We can plausibly conclude that objections to the Principle are the weakest possible. It is doubtful that anyone can propose an alternative principle to which someone else has a weaker objection. First, we can ask whether an alternative principle that stops short of the use of force, would be more reasonable. Target state citizens can reasonably reject an alternative principle that bans the use of force, lawfully used, as a last resort, because they will then have no opportunity to change their illegitimate state into a legitimate one, in circumstances in which such a change is warranted by definition, in the conditions set forth in the Self Governance Principle. Moreover, force is to be used only as a last resort

\footnotetext{
${ }^{88}$ Scanlon, What We Owe to Each Other, p. 204.

${ }^{89}$ Ibid., p. 205.
} 
and must comply with the laws of war. A good many intervening and target state citizens who would be harmed by use of force can obviously reasonably reject an alternative principle that does not so restrain the use of force. If we modify the collectivity constraints in the Self Governance Principle, to place the duty on single states, the citizens of intervening states would have reason to reject the Principle; a less burdensome collective Principle can be specified. Even citizens of non-intervening states would have reason to reject a Principle specifying a singular duty, since such a Principle could be destabilizing. If we modify the indirect duty constraints in the Self Governance Principle and require states to intervene directly, the intervening states' citizens would have reason to reject the Principle because of the great burdens placed on them by such a direct albeit collective duty. The attempts to produce successful collective action without institutions would be overly burdensome. Finally, removing the self determination and practical authority conditions would make the Self Governance Principle reasonably rejectable by many persons in both intervening and target states, who will suffer greatly from an unwarranted use of force to bring about a regime change in circumstances in which it is unlikely to successful.

The Self Governance Principle does not specify supererogatory action. To the extent criteria for what supererogatory action is can be agreed upon, the Self Governance Principle does not meet the criteria. In very general terms, supererogatory action is action beyond moral duty and not morally required but morally praiseworthy. The Self Governance Principle does not specify such acts. It does not specify morally praiseworthy action alone. Surely, obligatory action is morally praiseworthy, but it is more than that; its central feature is the demand in its content; it makes a moral demand on us we cannot refuse. The Self Governance Principle does just that. It specifies a duty of justice, of what is due the target state citizens, when the tightly specified conditions in the Principle are met. The Principle advises when justice requires persons to support collectively the actions of a national population to bring just institutions to their state. It does not specify a kind of exemplary peacemaking. Intervention to bring legitimacy in the form of justice to a state without meeting the two conditions specified in the Self Governance Principle may be seen as exemplary but it is more likely to be seen as folly or worse, given the harm it could wreak on many people, immoral. The saving feature of 
the Self Governance Principle is its strict specification of narrow conditions. The failure to use collective force to assist target state citizens to establish a legitimate state when they have expressed their desire for such a change would be to deny an improvement in the human condition that is uniquely valued: self governance. As explained above, self governance is central to human autonomy. We can rightly be blamed for failing to assist peoples who present to us the strict conditions for political self governance identified in the Self Governance Principle.

Resistance to the duty specified in the Self Governance Principle is likely to come from confusion that seems to exist in international law, in which all uses of force seem to receive the classification of a justification or permission, if not supererogation. The error may have originated in the legal analysis of use of force questions. The main source of confusion about talk of a "right" to engage in the use of force may come from the language of international law, stuck in the realm of politics and respect for state sovereignty. The result is inappropriate extension of language initially used to describe the "right" of states to use force in a more traditional form, that of the right to use force in self-defense. ${ }^{90}$ The terminology of self-defense is similar to that used in the criminal law on the right of self defense as a complete justification of an act that would otherwise be criminal. In the criminal law, it makes little sense to speak of an "obligation" of self defense, unless one is willing to conceptualize the discussion around duties to oneself. Certainly a moral duty to oneself of self defense exists, but the focus of the criminal law is in providing justification for exercising that moral duty in a way that does not result in harm to others. The terminology does not transfer well to entities, such as governments, which may owe obligations to their populaces to defend them against harm by other states, entities and persons. In any event, given that states have legal personality in international law, we use "right" when we refer to the right of a state to defend itself. ${ }^{91}$

These mistakes seem to have worked their way into discussions of humanitarian intervention, an admittedly even better candidate for obligatory action. Luban and others seek a "wider range of permissiveness" in which to act in the right cases of humanitarian

\footnotetext{
${ }^{90}$ It is doubtful that the self defense justification for the use of force is supererogatory. Self defense is not an action above and beyond the call of duty.

${ }^{91}$ These mistakes continue. Kok-Chor Tan rightly criticizes recent attempts by the international legal community to specify a "responsibility to protect" to justify humanitarian intervention. Tan, "The Duty to Protect," pp. 88-90. He argues that the lawyers conflate permission with obligation.
} 
intervention. ${ }^{92}$ Luban argues that humanitarian intervention may be "morally vital" but does not rise to the level of a moral duty. He contends that not all moral reasons rise to the level of obligation: "after all, not every reason for doing something is an obligation to do it." "93 He argues that bystander shame, not blame or moral guilt, is the reason that prompts us to intervene for humanitarian reasons. But taking action because you are ashamed is not taking supererogatory action. To take action to avoid shame is not praiseworthy or above and beyond the call of duty. Luban's account suggests that humanitarian intervention is something in the nature of a virtuous act, or at best a duty of beneficence. Certainly we believe there is a failure of moral accountability greater than shame or the failure to be charitable when we consider the recent spectacular failures of inaction by the international community in Rwanda and Sudan. The proper reaction is perhaps both shame and blame. If the international community were to have intervened in Rwanda or Sudan to stop the slaughters, they would not be doing something above and beyond moral duty. Such intervention is not simply praiseworthy and valuable; it is required.

Finally, does the Self Governance Principle contradict the Human Rights Principle? In the prior part, I argued that self governance does not justify humanitarian intervention. But I did not rule out use of force justified under some more finely grained principle. The Self Governance Principle is just that. It is an attempt to provide for a sufficiently determinate collective duty. The Self Governance Principle may be justified with a human rights argument, but I do not provide that argument here. The contractualist justification upon which the Self Governance Principle rests connects directly into notions of moral obligation.

\section{CONCLUSION}

Articulating a moral principle obligating states to use force not necessarily in response to force is difficult. Though the compelling features of other uses of force, such as mass atrocities or protection of vulnerable populations or self defense, may be absent in a regime change context, they do not have to be. Civil war, for example, may be

${ }^{92}$ Michael Walzer, “The Moral Standing of States: A Response to Four Critics,” Philosophy and Public Affairs 9(3) (1980): 209-229.

${ }_{93}$ Luban, "Intervention and Civilization: Some Unhappy Lessons of the Kosovo War,” p. 95. 
present in any process of national self determination. A civil war may send credible signals that the self determination conditions specified in the Self Governance Principle are met, but civil war is not explicit as a condition to make the Principle operative. What makes the Self Governance Principle morally attractive is its extreme limitations. The self determination and practical authority conditions provide for a very narrow range of application, limiting the ill effects of the use of military force on state legitimacy. The conditions require in all cases of regime change that legitimate moral and legal orders trump coercive order. The obligations the Self Governance Principle specifies, moreover, are not as great as they may seem at first blush; they in the main operate as a collective duty on legitimate states to form just and efficacious institutions to assist the populations of illegitimate states when the time is right.

Iraq was not a good candidate for regime change under the Self Governance Principle. There was no real collective action, force was not a last resort, the conditions for national self determination were not met, and the conditions for establishing a legal order meeting the practical authority conditions were not met. Iraq is a moral failure.

The Self Governance Principle does not sanction preventive war. The focus of the Principle is internal not external. The Principle specifies conditions for assisting people in governing themselves in a state that follows principles of justice. It does not specify conditions for intervention to prevent attacks on outsiders, though this may well be an important yet incidental benefit of the move to state legitimacy.

As explained at the beginning, the Self Governance Principle does not reflect the current state of international law. At most it could serve as a moral principle to inform the content of the legal rules yet to be specified. I agree with Buchanan, who says:

Violations of fundamental rules of existing international law, such as the prohibition against preventive war and against any use of force that does not qualify as self-defense and lacks Security Council authorization, are irresponsible, unless they are accompanied by a sincere effort to construct superior international legal structures to replace those they damage or render obsolete. ${ }^{94}$

We should take Buchanan's guidance seriously. We do not want state action to harm the legitimacy of international law. Buchanan's point takes us back to the beginning of the

\footnotetext{
${ }^{94}$ Buchanan, Justice, Legitimacy, and Self-Determination, p. 441.
} 
paper. Any armed intervention must itself be legitimate, having clear legal justification, and also must be seen to be legitimate, to be able to accomplish legitimate goals within a state. $^{95}$ Might does not make right.

${ }^{95}$ This is one of the basic premises of Stromseth, Wippman \& Brooks, Can Might Make Rights? 